предмет, а пов'язана з іншими предметами навчального плану. 4. Акцент на спрямування: змістовність розглядається як рушійна сила пізнання. 5. Індивідувальність: учні вчаться порізному і мають різні сильні сторони, ураховуються індивідуальні особливості учнів. 6. Особливості мисленнєвої діяльності: мова має служити засобом розвитку навичок критичного i творчого мислення. 7. Альтернативна оцінка: множинні форми оцінки (наприклад, спостереження, інтерв'ю, щоденники, портфоліо). 8. Творча співпраця вчителя й учнів: учитель розглядається як посередник, який постійно перевіряє різні альтернативи, тобто навчання відбувається через дію.

Отже, значна перевага комунікативного методу у становленні творчої особистості молодшого школяра полягає в тому, що процес навчання англійської мови будується адекватно реальному процесу мовленнєвого спілкування, тобто процес навчання $є$ моделлю процесу мовленнєвої комунікації. На жаль, процес навчання не може повністю збігатися 3 процесом комунікації, який має місце в реальному житті, оскільки навчання англійської мови в навчальних закладах відбувається в умовах рідномовного оточення. Тому йдеться тільки про максимальне зближення процесів навчання i реального спілкування за такими найважливішими параметрами, як комунікативно-вмотивована мовленнєва поведінка вчителя та учнів і предметність процесу спілкування. Недоліком комунікативного методу можна вважати недостатню увагу до формування граматичної компетентності учнів, оскільки наявна основна спрямованість на вдосконалення швидкості мовлення учнів та здатності висловлювати власні думки. Навчальна програма 3 іноземної мови в початковій школі передбачає використання різноманітних методів, але чітка організація дій учнів 3 навчальним матеріалом, оснащення навчального процесу необхідними засобами, що стимулюють і забезпечують розв'язання конкретних завдань, можуть вести до досягнення комунікативної мети і служити надійною основою для становлення творчої особистості у процесі навчання англійської мови на початковому етапі. Перспективою подальшої роботи $\epsilon$ створення експериментальної моделі формування комунікативної компетентності учнів початкових класів на уроках мови.

\title{
Література
}

1. Бадер В. Удосконалення мовленнєвого розвитку молодших школярів / В. Бадер // Педагогіка і психологія. - 1998. - № 4. - С. 31-36. 2. Барановська Л. В. До теоретичних засад формування культури мовлення / Л. В. Барановська // Педагогіка і психологія. - 1997. № 3. - С. 33-37. 3. Гаркуша В. В. Формирование навыков общения и коммуникативных способностей в процессе личностно-ориентированного обучения устной иноязычной речи : дис. на соискание ученой степени канд. психол. наук / Гаркуша В. В. - Днепропетровск, 1992. - 129 с. 4. Зимняя И. А. Психология обучения иностранным языкам в школе/ И. А. Зимняя. - Москва : Просвещение, 1991. - 222 с. 5. Richards J. Commuticative teaching today / J. Richards. - Cambridge, 2006. -42 p.

\section{ФОРМУВАННЯ ЕКОЛОГІЧНОГО СВІТОГЛЯДУ МАЙБУТНІХ УЧИТЕЛІВ ПОЧАТКОВОЇ ШКОЛИ У ПРОЦЕСІ ПРОФЕСІЙНОЇ ПІДГОТОВКИ}

Грошовенко О. П. Формування екологічного світогляду майбутніх учителів початкової школи у процесі професійної підготовки.

У статті актуалізується необхідність посилення гуманістичного складника системи 
освіти України, забезпечення пріоритетності загальнолюдських цінностей, орієнтації навчально-виховного процесу у вищих навчальних закладах, насамперед на процеси формування особистості у всій багатогранній повноті iї інтелектуального, культурного, психологічного й соціального розвитку. Формування екологічного світогляду майбутніх вчителів початкової школи визначено як цілісну систему формування особистості, спрямовану на реалізацію сучасних освітніх завдань у контексті гуманістичної парадигми.

У контексті розв'язання проблеми формування екологічного світогляду обгрунтовано необхідність употужнення професійної підготовки майбутніх учителів початкової ланки освіти, забезпечення їх знаннями тих моделей природничої освіти, які допомагають впливати на формування цілісної картини світу молодших школярів, розкриття їхніх здібностей, забезпечення реалізації принципів інтегративності природничої освіти, практичної спрямованості, екологізації та естетизації навчально-виховного процесу.

Ключові слова: гуманітаризація, гуманізація, екологічний світогляд, учитель початкової школи, професійна підготовка, модель природничої освіти.

Грошовенко А. П. Формирование экологического мировоззрения будущих учителей начальной школы в процессе профессиональной подготовки.

В статье актуализируется необходимость усиления гуманистической составляющей системы образования Украины, обеспечение приоритетности общечеловеческих ценностей, ориентации учебно-воспитательного процесса в высших учебных заведениях, прежде всего на процессы формирования личности во всей многогранной полноте ее интеллектуального, культурного, психологического и социального развития. Формирование экологического мировоззрения будущих учителей начальной школы определяется как целостная система формирования личности, направленная на реализацию современных образовательных задач в контексте гуманистической парадигмы.

В контексте решения проблемы формирования экологического мировоззрения обоснована необходимость усиления профессиональной подготовки будущих учителей начального звена образования, обеспечения их знаниями тех моделей естественного образования, которые помогают влиять на формирование целостной картины мира младших школьников, это способствует раскрытию их способностей, обеспечивает реализацию принципов интегративности естественнонаучного образования, практической направленности, экологизации и эстетизации учебно-воспитательного процесса.

Ключевые слова: гуманитаризация, гуманизация, экологическое мировоззрение, учитель начальной школы, профессиональная подготовка, модель естественного образования.

Hroshovenko O. P. Formation of ecological world outlook of future primary school teachers in the course of professional training.

This article reveals the necessity of humanistic component intensification in Ukrainian educational system, ensuring the priority of mankind values, orientation of educational process in higher schools first of all on personality formation process in all aspects of intellectual, cultural, psychological and social development. Formation of ecological world outlook of future primary school teachers is determined as an integral system of personality formation, aimed at realization of modern educational goals in the context of humanistic paradigm.

In the context of solving the problem of ecological world outlook formation the necessity to strengthen the professional training of future primary school teachers and to provide them with the 
knowledge of natural education models which influence on the formation of holistic view of the world of junior pupils is grounded. This promotes the development of their skills, provides the implementation of the principles of integrity of natural science education, practical orientation, greening and aesthetucuzation of the educational process.

Key words: humanitarization, humanization, ecological world outlook, primary school teachers, professional training, ecological education model.

Реформування системи освіти України актуалізує необхідність посилення іiі гуманістичної складової, що ставить особливі вимоги до вищої освіти і зумовлює іiі мету на сучасному етапі. Стратегічні завдання вищої освіти визначено в Законі України «Про вищу освіту» [4], Національній доктрині розвитку освіти [5], Державній національній програмі «Освіта» («Україна XXI століття)) [2]. 3-поміж головних принципів реалізації означених програм визначено принцип гуманізації освіти, який відображає спрямованість розвитку освіти на гуманні стосунки, утвердження людини як вищої соціальної цінності, розкриття іiі здібностей, задоволення різноманітних освітніх потреб, забезпечення пріоритетності загальнолюдських цінностей, гармонії стосунків людини і навколишнього середовища, суспільства і природи [1].

Проблема гуманізації освіти розкрита у психолого-педагогічних теоріях розвитку людини Л. Виготського, С. Рубінштейна, М. Мамардашвілі, Ж. Піаже, А. Маслоу, К. Роджерса на ін. Сучасні підходи до здійснення гуманістичного виховання розкрито у працях І. Беха, О. Бондаревської, М. Боришевського, О. Вишневського, С. Гончаренка, Г. Жирської, О. Киричука, Ю. Мальованого, І. Підласого, О. Савченко, Г. Тарасенко та ін. Наявний науковий фонд є свідченням особливої актуальності проблеми гуманізації освіти у контексті розв'язання завдань формування цілісної картини світу, духовності, культури особистості.

Державна національна програма «Освіта» («Україна XXI століття») викремлює принципи гуманізації і гуманітаризації освіти і дає їм такі визначення.

Гуманізація - це процес створення умов для самореалізації, самовизначення студентів, орієнтація навчально-виховного процесу у вищих навчальних закладах, насамперед на процеси формування особистості у всій багатогранній повноті іï інтелектуального, культурного, психологічного і соціального розвитку. Гуманізація освіти полягає в утвердженні людини як найвищої соціальної цінності, розкритті здібностей учнів і задоволенні їхніх освітніх потреб; забезпеченні пріоритету загальнолюдських цінностей, гармонії стосунків людини і навколишнього середовища, суспільства і природи [2].

Гуманітаризація - це підвищення питомої ваги соціально-економічних та інших гуманітарних навчальних дисциплін, удосконалення їх змісту й методики викладання задля формування та забезпечення розвитку високих моральних якостей випускників вищих навчальних закладів. Гуманітаризація освіти покликана формувати цілісну картину світу, духовність, культуру особистості та планетарне мислення [2].

Meта cmammi- обгрунтування необхідності забезпечення підготовки майбутніх учителів початкової ланки освіти до реалізації моделі формування цілісної картини світу молодших школярів.

Професійна підготовка майбутніх учителів початкової ланки освіти $є$ однією 3 найактуальніших і соціально значущих проблем сучасної системи вищої освіти, провідною метою якої $\epsilon$ формування конкурентоспроможного фахівця, здатного 3 максимальною користю для суспільства реалізовувати свій творчий потенціал. Аналіз системи професійної 
підготовки майбутнього вчителя початкової школи та сучасних тенденцій розвитку освіти надає змогу констатувати посилення диференціації наукових напрямів, підвищення статусу технократичних і зниження статусу гуманістичних цілей. Процеси реформування системи вищої освіти неодмінно стосуються галузей, які перебувають у тісному взаємозв'язку із природознавством, підготовкою майбутнього вчителя до викладання природничих дисциплін у школі I ступеня. Так, традиційна система освіти характеризується таким підходом до змісту освіти, за якого знання є єдиною цінністю. Результатом активізації такого напрямку є дегуманізація освіти, яка в принципі суперечить стратегічним потребам суспільства, особливостям фахової підготовки майбутнього вчителя.

Гуманістичний світогляд - основа духовного потенціалу суспільства, складниками якого є можливості самої людини, розвиток яких певною мірою залежить від рівня науки, культури і освіти. Другорядне ставлення до цих цінностей нині провокує духовне зубожіння людей, тому ми й розглядаємо гуманізацію як засіб створення духовного потенціалу та одну із засад, на основі якої має відбуватися професійна підготовка майбутнього вчителя. Особливо це стосується системи підготовки майбутнього вчителя початкової школи.

Сучасний педагог повинен володіти високими кваліфікаційними характеристиками, бути готовим до здійснення інноваційної діяльності, вміти виробляти індивідуальний педагогічний стиль. Основними напрямами підготовки майбутнього вчителя початкової школи є комплекс методологічних, педагогічних та методичних проблем, які розв'язуються через залучення студентів вищої школи до здобуття теоретичних знань та практичної педагогічної діяльності, спрямованої на підвищення рівня їхнього професіоналізму.

Аналіз сучасних навчальних планів підготовки майбутніх учителів початкової школи засвідчив наявність широкого кола суперечностей між змістом шкільної природничої освіти й соціальним запитом, необхідністю формування цілісної картини світу, природничої компетентності молодших школярів та особливостями професійної підготовки вчителя. Тому, невідповідності у професійній підготовці майбутнього вчителя позначаються на його неготовності до використання специфічних для природничої освіти методів, прийомів, форм, технологій. Переконуємося в тому, що нині дидактична та методична підготовка майбутніх учителів початкових класів потребує удосконалення.

Сучасний навчальний план вищих педагогічних закладів, який відображає зміст професійної підготовки майбутніх учителів початкової школи до викладання природничих дисциплін передбачає вивчення таких дисциплін: «Методика навчання освітньої галузі «Природознавство», «Методика навчання освітньої галузі «Суспільствознавство». Безперечно, у системі фахової підготовки майбутнього вчителя початкових класів ці навчальні дисципліни посідають вагоме місце, мають великий інтеграційний потенціал, зумовлений безпосередньою практичною спрямованістю. Їх метою $\epsilon$ підготовка висококваліфікованого фахівця, здатного конструювати цілісний процес навчання в різноманітних формах і методах організації, прогнозувати його та здійснювати педагогічне управління відповідно до специфіки змісту навчального предмета i психологічних можливостей дітей молодшого шкільного віку.

Від рівня фахової підготовки вчителя початкових класів, високого професіоналізму майбутніх фахівців, становлення в них нового мислення, формування умінь демонструвати індивідуальний стиль педагогічної діяльності, готовності творчо працювати, самовдосконалюватися, упроваджувати нові підходи до організації і здійснення навчального процесу в молодших класах залежить ефективність навчально-виховного процесу в початковій школі. Наразі відбувається активний пошук гуманістичних концепцій і моделей 
освіти, методів, технологій навчання і виховання майбутніх педагогів, 3-поміж яких завдання підготовки студентів до формування цілісної картини світу молодших школярів має вагоме значення.

Майбутній учитель початкових класів повинен знати, що навчально-пізнавальний процес у початковій школі базується на компетентнісно орієнтованих завданнях із використанням сучасних освітніх технологій (розвиток критичного мислення та креативності, проблемний підхід, проектні технології). Викладання предметів «Природознавство», «Я у світі» вимагає використання вчителем місцевого природознавчого та краєзнавчого матеріалу, проведення регулярних екскурсій. Важливе значення для емоційно-естетичного сприйняття природи молодшими школярами відіграватимуть спостереження за природою, дидактичні ігри, уроки, проведені у формі подорожі, усного журналу, репортажу з місця подій, святкування дня Землі, космонавтики, прильоту птахів, власні дослідження, творчі завдання, екологічні акції тощо. Зважаючи на це, майбутній учитель повинен володіти методикою проведення таких навчальних занять, мати грунтовні теоретичні знання, вміти застосовувати інноваційні методики, інформаційно-комунікаційні засоби.

Одним 3 основних шляхів виконання завдань формування висококваліфікованого, обізнаного вчителя є реалізація в педагогічному процесі вищого навчального закладу принципу гуманізації навчання. Цей принцип є визначальним у системі фахової підготовки майбутніх учителів початкової школи, бо його сутність полягає у визнанні самоцінності кожної людини, забезпеченні її особистісної свободи й можливостей максимальної реалізації творчого потенціалу.

Актуальність проблеми підготовки майбутніх учителів початкової школи до реалізації гуманістичного підходу підкреслюється затвердженням Державного стандарту початкової загальної освіти, який розроблено відповідно до мети початкової школи 3 урахуванням пізнавальних можливостей і потреб учнів початкових класів. Державний стандарт початкової загальної освіти визначає їі зміст, який грунтується на загальнолюдських цінностях та принципах науковості, полікультурності, світського характеру освіти, системності, інтегративності, єдності навчання i виховання на засадах гуманізму, демократії, громадянської свідомості, взаємоповаги між націями і народами в інтересах людини, родини, суспільства, держави; базується на засадах особистісно зорієнтованого і компетентнісного підходів, що зумовлюють чітке визначення результативного складника засвоєння змісту початкової загальної освіти [3].

Гуманізація і гуманітаризація освітнього процесу надзвичайно важливі під час формування у молодших школярів природничо-наукової та соціальної компетентності як обов’язкового складника загальної культури особистості для розв'язання глобальних проблем людства. Забезпечення під час навчання принципів гуманізації і гуманітаризації освіти - переорієнтації освіти з предметно-змістового принципу навчання основ наук на вивчення цілісної картини світу і формування в учнів гуманітарного й системного мислення.

Варто наголосити, що вивчення предметів «Природознавство», «Я у світі» не може повною мірою задовольнити розкриття здібностей учнів та формування їхніх освітніх потреб. Розв'язання завдання формування цілісної картини світу як складової частини гуманітаризації освіти також неможливе в межах цих навчальних предметів. Одним із недоліків сучасної предметно-диференційованої освітньої системи є відсутність цілісних уявлень про навколишній світ. Тому пріоритетного значення набувають ті моделі природничої освіти, які допомагають впливати на формування цілісної картини світу 
молодших школярів, розкриття їхніх здібностей, забезпечення реалізації принципів інтегративності природничої освіти, практичної спрямованості, екологізації й естетизації навчально-виховного процесу.

Проблема інтеграції змісту природничої шкільної освіти, формування «образу природи» учня як його суб'єктивної природничо-наукової картини світу розв'язується в авторській естетико-екологічній технології Г. Тарасенко [6]. У контексті реалізації гуманістичної парадигми освіти естетико-екологічна технологія передбачає забезпечення гармонії взаємовідносин людини і навколишнього середовища, суспільства і природи (гуманізація) і формування планетарного мислення (гуманітаризація) здійснюється через усебічне відображення стосунків людини й довкілля. Пропонована автором модель природничої освіти забезпечує реалізацію взаємозв'язку гуманізації і гуманітаризації освіти, сприяє розкриттю здібностей та задоволення освітніх потреб молодших школярів, забезпечення пріоритету загальнолюдських цінностей, гармонії взаємовідносин людини та навколишнього середовища, суспільства і природи. Застосування технологій естетикоекологічного виховання сприяє формуванню цілісної картини світу, духовності та культури особистості, планетарного мислення. Визначення ефективних методів засвоєння гуманітарного компонента «образу природи» учня у контексті цілісності пов'язана 3 додатковим дослідженням найбільш вдалих форм інтеграції змісту навчання. Особливу увагу за реалізації принципу гуманітаризації природничої освіти приділено інтегративним формам навчання.

У навчально-виховному процесі ВНЗ необхідно реалізовувати сучасні принципи організації навчального процесу, вдосконалювати зміст і структуру, форми та методи підготовки фахівців через пріоритет гуманістичної парадигми, оволодіння повною мірою педагогікою співробітництва, заснованою на діалогічному спілкуванні, розширення переліку гуманітарних дисциплін, поглиблення інтеграції їх змісту для отримання системного знання.

Гуманізація природничо-наукової освіти - процес, спрямований на формування особистості як найвищої соціальної цінності на засадах критеріїв моральності, краси, загальнолюдських цінностей. Гуманітаризація природничо-наукової освіти - процес, який сприяє формуванню духовності й культури особистості учнів через використання методів, що розроблені в галузі гуманітарних дисциплін. Щоб забезпечити сучасне суспільство висококваліфікованими фахівцями, навчально-виховний процес має акцентувати увагу на перевагах використання в системі вищої освіти гуманістичних принципів, форм і методів навчально-виховної роботи.

Пропонована модель природничої освіти та іï реалізація в царині професійної підготовки майбутніх учителів початкової школи сприятиме зміні світогляду майбутніх фахівців, усвідомленню ними розуміння і сприйняття людини як найвищої цінності суспільства, розвитку особистості студента, виробленню навичок і вмінь у майбутній гуманістично-орієнтованій професійній діяльності.

Перспективи подальших розвідок убачаємо у вивченні педагогічних умов професійної підготовки майбутнього вчителя початкової школи до реалізації моделі формування цілісної картини світу молодших школярів.

\section{Література}

1. Гончаренко С. У. I все таки - гуманізація / С. У. Гончаренко // Педагогіка i психологія. - 1995. - № 1. - С. 7. 2. Державна національна програма «Освіта» («Україна XXI століття»). - Київ : Райдуга, 1994. - 61 с. 3. Державний стандарт початкової загальної освіти // Початкова школа. - 2011. - № 18 (594). - 43 с. 4. Закон України «Про вищу освіту» 
від 17 січня 2002 р. № 2984 // Офіційний вісник України. - 2002. - № 8. - С. 3-43. 5. Національна доктрина розвитку освіти // Офіційний вісник України. - 2002. - № 16. - С. 2 14. 6. Тарасенко Г. С. Дивосвіт. Технологія естетико-екологічного виховання / Г. С. Тарасенко. - [2-ге вид., із змін.]. - Київ: Рута, 2000. - 208 с. 7. Тарасенко Г. С. Взаємозв'язок естетичної та екологічної підготовки вчителя в системі професійної освіти: [монографія] / Г. С. Тарасенко. - Черкаси: «Вертикаль», ПП Кандич С. Г., 2006. - 308 с.

\section{РЕАЛІЗАЦІЯ КОМПЕТЕНТНІСНОГО ПЦДХОДУ ПІД ЧАС ФОРМУВАННЯ В МОЛОДШИХ ШКОЛЯРІВ НАВИЧОК МОВНИХ РОЗБОРІВ}

Жигора І. В. Реалізація компетентнісного підходу під час формування в молодших школярів навичок мовних розборів.

У статті проаналізовано поняття компетентнісного підходу під час формування в молодших школярів навичок мовних розборів. Основну увагу зосереджено на мовному розборі як показнику обізнаності (компетентності) учнів початкових класів у певному мовному матеріалі. Мовний розбір досліджується як засіб узагальнення та систематизації набутих знань учнів з української мови, що сприяє роботі над формуванням загальномовної компетентності учнів початкових класів.

Ключові слова: компетентнісний підхід, мовна компетентність, мовний розбір, мовний аналіз.

Жигора И. В. Реализация компетентностного подхода в процессе формирования у младших школьников навыков языковых разборов.

В статье проанализировано понятие компетентностного подхода в процессе формирования у младших школьников навыков языковых разборов. Основное внимание уделено языковому разбору как показателю компетентности учеников начальных классов в конкретном языковом материале. Языковой разбор рассматривается как способ обобщения и систематизации полученных знаний учениками по украинскому языку, что способствует работе над формированием общеязыковой компетентности учеников младших классов.

Ключевые слова: компетентностный подход, языковая компетентность, языковой разбор, языковой анализ.

Zhigora I. V. The implementation of competence-based approach in the process of formation of primary pupils' linguistic analysis skills.

In the article the concept of competence-based in the process of formation of primary pupils' linguistic analysis skills has been analyzed. The main focus was made on the linguistic analysis as a level of primary school pupils' competence in the certain linguistic material. Linguistic analysis is studied as a means of generalization and systematization of acquired knowledgeof Ukrainian language, which contributes to the formation of general linguistic competence of primary school pupils.

Key words: competence-based approach, linguistic competence, linguistic parsing, linguistic analysis. 